\title{
Photosynthesis and Growth of Copaiba Seedlings Subjected to Soil Flooding
}

\author{
Daniela Baldez Vidal ${ }^{1}$ (D), Isis Leite Medeiros Mascarenhas Andrade ${ }^{1}$ (D), \\ Ândrea Dalmolin ${ }^{1}$ (D), Marcelo Mielke ${ }^{1}$ \\ ${ }^{1}$ Departamento de Ciências Biológicas, Universidade Estadual de Santa Cruz - UESC, Ilhéus (BA), Brasil
}

\begin{abstract}
The present study aimed to evaluate the effects of soil flooding on photosynthesis, growth, and biomass partitioning of young plants of copaiba (Copaifera lucens Dwyer, Fabaceae) to investigate the possibility of using this species in restoration projects of riparian forests. Based on our results, we concluded that young plants of $C$. lucens are able to tolerate soil flooding for a period of approximately one month, despite significant decreases in the growth rate of roots, stomatal conductance to water vapor, and the net photosynthetic rate. These results indicate the possibility of including $C$. lucens in restoration programs for degraded riparian forests in regions where this species naturally occurs.
\end{abstract}

Key-words: Copaifera lucens, stomatal conductance, net photosynthetic rate, relative growth rate. 


\section{INTRODUCTION}

Riparian forests have great environmental importance, acting as ecological corridors in the stabilization of water flow in streams and rivers, and the protection of public supply reservoirs (Tundisi \& Tundisi, 2010). However, most riparian forests in environments of the Brazilian Atlantic Rainforest are in an advanced state of degradation (Moraes et al., 2012). The degradation process of riparian forests has resulted in several environmental problems, including the extinction of fauna and flora species, local climate changes, soil erosion, and eutrophication of watercourses (Ferreira \& Dias, 2004). Due to their importance and the current state of degradation of riparian forests in the Brazilian Atlantic Rainforest, initiatives have arisen for restoring these ecosystems. However, due to the oscillation of water levels in rivers, lakes, and reservoirs, local riparian forests are difficult to reforest because these water level variations create extreme conditions caused by the seasonal or eventual flooding of the soil (Lobo \& Joly, 2000; Kozlowski, 2002).

Random events, such as flooding caused by excessive rainfall, can lead to total or partial flooding of plants in riparian forest environments. During total flooding, there is complete submersion of individual plants, which causes damage to roots, and changes in the photosynthetic rate and fall of leaves (Gonçalves et al., 2012; Parolin, 2012; Maxwell et al., 2016). Thus, soil flooding may cause damage to the roots and visible but indirect changes in the aerial plant parts (Mielke et al., 2003; Medri et al., 2007; Oliveira \& Joly, 2010). Although situations of occasional total flooding might cause more deleterious effects (Gonçalves et al., 2012), the complete submersion of seedlings usually persists for only a few days. Inversely, soil flooding can persist for days or weeks, depending on the flood intensity and soil drainage capacity. In addition, fully submerged plants are also subject to soil flooding.

Floods eliminate the air spaces in the soil, which limits the gas exchange between the soil and atmosphere, and within few hours the roots and microorganisms consume the oxygen present in the water, creating a hypoxic or anoxic environment (Kozlowski, 2002; Kozlowski \& Pallardy, 2002). Plant responses to soil flooding may include premature foliar senescence, decreased root and shoot volume, adventitious root formation, aerenchyma and hypertrophic lenticels, as well as decreases in stomatal conductance and net photosynthetic rate (Kozlowski, 2002; Kozlowski \& Pallardy, 2002; Mielke et al., 2003; Medri et al., 2007; Mielke \& Schaffer, 2010; Oliveira \& Joly, 2010; Santos et al., 2012; Gonçalves et al., 2012; Lira et al., 2013; Gonçalves et al., 2013; Herrera, 2013). Young plants tend to be more vulnerable than adult plants to the stresses imposed by floods (Maxwell et al., 2016).

In general, high survival and growth rates of plants subjected to soil flooding are related to the formation of lenticels and aerenchyma, and the ability of the plants to maintain stomatal conductance and net photosynthetic rates at levels that allow survival and growth when the roots are under limited oxygen availability (Lopez \& Kursar, 1999; Mielke et al., 2003; Medina et al., 2009; Oliveira \& Joly, 2010; Li et al., 2015).

According to the aforementioned, biochemical, physiological, anatomical, and morphological responses of different species when subjected to soil flooding conditions are an important strategy for planning and analysis of procedures adopted in restoration projects of degraded riparian forests (Mielke et al., 2003; Medri et al., 2007; Mielke \& Schaffer, 2010; Lira et al., 2013; Li et al., 2015).

Species of the genus Copaifera produce economically profitable medicinal oil and are adapted to a wide variety of environments. Species occur in Terra Firme forests, wetlands, lakesides, and Igarapés in the Amazon Basin and the Cerrado forests of Central Brazil (Rigamonte-Azevedo et al., 2004). In the Brazilian Atlantic Forest, Copaifera species are found in ombrophilous and semi-deciduous forests, and in primary, secondary, and riparian forest (Sambuichi, 2009). In an earlier study, Vidal et al. (2014) verified that $C$. lucens seeds are partially tolerant to submersion in water and are a promising species to utilize in the direct sowing technique in ciliary forest restoration projects. Despite this, there have been no studies previously published in the literature on the effects of partial flooding, or soil flooding, on the physiological performance and growth of C. lucens.

The present study aimed to evaluate the effects of soil flooding on photosynthesis, growth, and biomass partitioning of young plants of C. lucens, with the aim to analyze the possibility of using this species in restoration projects of degraded riparian forests. 


\section{MATERIAL AND METHODS}

The experiment was undertaken in a nursery at the Plant Physiology Laboratory of the State University of Santa Cruz (Universidade Estadual de Santa Cruz - UESC), Ilhéus, Bahia, Brazil. Seeds were collected from the Terra Vista Settlement, Arataca, Bahia, Brazil, in August 2010 by technicians of the UESC's herbarium (HUESC). After collection, the seeds were sterilized and sowed in litter boxes containing washed and autoclaved sand. 62 days after sowing, the seedlings were transferred to $100 \times 200 \mathrm{~mm}$ polyethylene plastic bags containing forest soil, which were transported to the nursery. 40 days after transplantation, 30 plants were selected, which were conditioned in $100 \times 260 \mathrm{~mm}$ PVC pipes, with a lid at the lower end and containing approximately $20 \mathrm{~mm}$ of gravel. Two holes were made in the PVC pipe lids, one on each side, to drain the irrigation water. Nine days after plant selection and conditioning in the PVC pipes, basic phosphate fertilization (700g of $\mathrm{P}_{2} \mathrm{O}_{5}$ per $\mathrm{m}^{3}$ of substrate) was added. Phosphorus was applied together with nitrogen and potassium ( $40 \mathrm{~g}$ of nitrogen and $40 \mathrm{~g}$ of $\mathrm{K}_{2} \mathrm{O}$ per 100 sachets) with an interval of 14 days between each fertilization, which was always carried out at the end of the afternoon. The fertilizers used were monoammonium phosphate and potassium nitrate. Fertilizers were applied to avoid the possibility of an additional stress that could interfere in the physiological performance of the plants during the experiment. At the commencement of flooding, the plants were six months old and approximately $20 \mathrm{~cm}$ high. Flooding was achieved by capping the two side holes of the lower end of the PVC pipes and filling them with water to $20 \mathrm{~mm}$ above ground level for a period of 39 days. This period was chosen because it is longer than the floods that occasionally occur in riparian forest environments. The control plants were irrigated daily during the entire experimental period.

At the beginning of the flood, the dry mass of roots (RDM), stems (SDM), leaves (LDM), and total (TDM) were evaluated in 10 plants, in addition to the total leaf area per plant (LA). The plant material was placed individually in paper bags, properly identified, and dried in a forced ventilation oven at $75^{\circ} \mathrm{C}$ until constant mass, for $72 \mathrm{~h}$. The leaf area (LA) was obtained using an automatic leaf area meter LI-3100 (Li-Cor, EUA).
The presence of lenticels in flooded plants was evaluated at 16 and 37 days after flooding began using an index ranging from 0 to 3 , where 0 indicated no lenticels, 1 indicated a few visible lenticels, 2 indicated some visible lenticels, and 3 indicated many visible lenticels.

At 37 days after flooding, the net photosynthetic rate (A) and stomatal conductance to water vapor (gs) were evaluated using a portable photosynthesis meter model Li-6400 (Li-Cor, USA), equipped with an artificial light source 6400-02B RedBlue, programmed to provide $1,200 \mu \mathrm{mol}$ photons $\mathrm{m}^{-2} \mathrm{~s}^{-1}$. During the measurements, the leaf temperature was maintained at $30 \pm 1{ }^{\circ} \mathrm{C}$, the air relative humidity was approximately $60 \pm 0.4 \%$, and the ambient $\mathrm{CO}_{2}$ concentration was approximately $387 \pm 3 \mu \mathrm{mol} \mathrm{mol}^{-1}$. Measurements were taken between 8 am and $10 \mathrm{am}$, using the apical leaflet of a mature leaf that was completely expanded per plant, in 15 plants per treatment. The intrinsic water use efficiency was calculated as the ratio between $\mathrm{A}$ and gs (A/gs).

At 39 days after flooding, the total chlorophyll content obtained from the SPAD index (SPADi) was estimated using a portable SPAD-502 chlorophyll meter (Minolta, Japan). Soon after, the flooded and non-flooded plants were harvested for LA, RDM, SDM, LDM, and TDM evaluations, following the same procedures described above. The root mass ratio $(\mathrm{RMR}=\mathrm{RDM} / \mathrm{TDM})$, stem mass ratio $(\mathrm{SMR}=\mathrm{SDM} / \mathrm{TDM})$, leaf mass ratio $(\mathrm{LMR}=\mathrm{LDM} / \mathrm{TDM})$, and leaf area ratio $(\mathrm{LAR}=\mathrm{LA} / \mathrm{TDM})$ were calculated. Based on dry mass data obtained at the beginning and end of flooding, we calculated the relative growth rates of roots (RGRr), stems (RGRs), leaves (RGRl) and total (RGRt) and net assimilatory rate (NAR) based on the method described by Hunt et al. (2002) using the formulas $\mathrm{RGR}=\left(\operatorname{lnDM}_{2}-\operatorname{lnDM}_{1}\right) / \mathrm{t}$ and $\mathrm{NAR}=\left[\left(\mathrm{TDM}_{2}-\mathrm{TDM}_{1}\right) / \mathrm{t}\right] \times\left[\left(\operatorname{lnLA}_{2}-\operatorname{lnL} A_{1}\right) /\left(\mathrm{LA}_{2}-\mathrm{LA}_{1}\right)\right]$; where indices 1 and 2 represent the initial and final values, and $\mathrm{t}$ is the number of days between harvests. For RGR, DM is the dry mass of roots (RDM), stems (SDM), leaves (LDM) or total per plant (TDM).

The experimental design was completely randomized with 2 soil water levels (flooded and control), 15 replicates for biomass and SPADi, and 10 replicates for leaf gas exchange. The comparisons of means were performed using the t-test. 


\section{RESULTS}

Plants subjected to flooding conditions did not present symptoms of flood stress such as chlorosis, epinasty, senescence, and foliar abscission, but did develop hypertrophied lenticels (Figure 1). After 16 days of flooding, some lenticels had become visible and at 37 days after flooding all the flooded plants had lenticels. The roots of the flooded plants had darker coloration than the control plants and some roots of the flooded plants had a strong odor.

At 37 days after flooding, significant differences were observed between treatments for $\mathrm{A}$ and $\mathrm{gs}$ ( $\mathrm{p} \leq 0.01$; $\mathrm{t}$-test) (Table 1). The mean values of $\mathrm{A}$ and gs were approximately $80 \%$ lower in the flooded plants than in the non-flooded plants. There were no significant differences between treatments for the $\mathrm{A} / \mathrm{gs}$ ratio ( $\mathrm{p}>0.05$; t-test).

Non-significant differences between non-flooded and flooded plants were observed for RGRs, RGRl, RGRt, NAR, LA, LMR, LAR, and SPADi ( $>$ > 0.05; t-test) after 39 days from the beginning of flooding

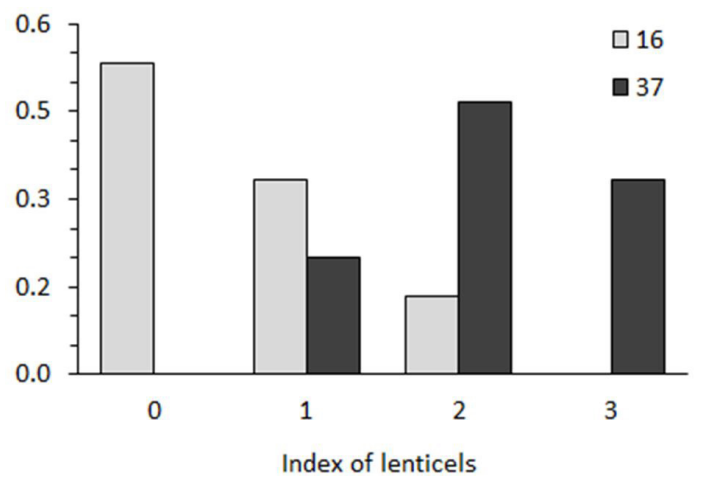

Figure 1. Frequency distribution for the index of presence of lenticels ( 0 - no lenticels; 1 - few visible lenticels; 2 - some visible lenticels; 3 - many visible lenticels) of young plants of C. lucens at 16 and 37 days after the beginning of soil flooding.
(Table 2). There were significant differences between treatments for tRGR, SMR, $(\mathrm{p} \leq 0.05$, $\mathrm{t}$-test $)$, and RMR $(\mathrm{p} \leq 0.01, \mathrm{t}$-test $)$.

Except for SMR, LMR, LAR, and SPADi, all other analyzed variables presented higher values in non-flooded plants than in flooded plants. Even though no significant differences between treatments were observed, the mean RGRl and RGRt values were approximately $25 \%$ lower in the flooded plants than in the non-flooded plants. The highest percentage difference between treatments was observed for the RGRr, which was approximately $70 \%$ lower in the flooded plants than in the non-flooded plants.

\section{DISCUSSION}

Plants subjected to soil flooding have different responses in biochemical, physiological, anatomical, and morphological levels (Lobo \& Joly, 2000). Many of these responses manifest themselves through visual symptoms and can result in either acclimatization or plant death. The young plants of $C$. lucens used in the present study survived flooding of the soil for 39 days without presenting visual symptoms of stress, such as epinasty, chlorosis, or leaf fall (Kozlowski \& Pallardy, 2002). In addition, the appearance of lenticels at the base of the stems were very visible, which is a visual symptom of acclimatization to flooding that has also been observed in other tree species, such as Cecropia pachystachya, (Batista et al., 2008), Erythrina speciosa (Medina et al., 2009), Lithraea molleoides (Medri et al., 2007), Tabebuia avellanedae (Davanso et al., 2002), and Lonchocarpus sericeus (Lira et al., 2013). Although the flooded plants survived the soil flooding, they presented decreased growth rates and darkening of the roots.

Oliveira (2012) verified that young plants of C. langsdorffii subjected to soil flooding for 30 days presented a decrease in root growth, with roots becoming dark in color and showing the beginning

Table 1. Net photosynthetic rate (A), stomatal conductance (gs), and intrinsic water-use efficiency (A/gs) for young plants of $C$. lucens subjected to soil flooding for 37 days. Means \pm standard errors $(n=10)$.

\begin{tabular}{cccc} 
Variable & Non-flooded & Flooded & \% Control \\
\hline $\mathrm{A}\left(\mu \mathrm{mol} \mathrm{m} \mathrm{m} \mathrm{s}^{-1}\right)$ & $6.25 \pm 0.70$ & $1.34 \pm 0.38^{* *}$ & 16 \\
\hline $\mathrm{gs}\left(\mathrm{mmol} \mathrm{m}^{-2} \mathrm{~s}^{-1}\right)$ & $53.8 \pm 8.1$ & $8.6 \pm 1.8^{* *}$ & 21 \\
$\mathrm{~A} / \mathrm{gs}\left(\mu \mathrm{mol} \mathrm{mmol}{ }^{-1}\right)$ & $120.8 \pm 8.1$ & $129.6 \pm 18.5^{\mathrm{ns}}$ & 107 \\
\hline
\end{tabular}

Statistical significance between non-flooded and flooded plants is given by the $\mathrm{t}$-test $\left({ }^{\mathrm{ns}} \mathrm{p}>0,05 ;{ }^{* *} \mathrm{p} \leq 0.01\right)$. 
Table 2. Relative growth rates of root (RGRr), steam (RGRs), leaves (RGRl) and total (RGRt), net assimilation rate (NAR), leaf area (LA), root (RMR), steam (SMR), leaves (LMR) mass ratios, leaf mass ratio (LAR), and SPAD index (SPADi) of young plants of C. lucens subjected to soil flooding for 39 days. Means \pm standard errors $(\mathrm{n}=15)$.

\begin{tabular}{|c|c|c|c|}
\hline Variable & Non-flooded & Flooded & $\%$ Control \\
\hline $\operatorname{RGRr}\left(\mathrm{mg} \mathrm{g}^{-1}\right.$ day $\left.^{-1}\right)$ & $13.97 \pm 2.78$ & $3.98 \pm 2.70^{*}$ & 29 \\
\hline RGRs (mg g ${ }^{-1}$ day $^{-1}$ ) & $15.37 \pm 1.83$ & $14.45 \pm 2.09^{\mathrm{ns}}$ & 94 \\
\hline RGRl (mg g ${ }^{-1}$ day $\left.^{-1}\right)$ & $9.85 \pm 2.34$ & $7.00 \pm 2.21^{\mathrm{ns}}$ & 71 \\
\hline RGRt (mg g ${ }^{-1}$ day $\left.^{-1}\right)$ & $12.84 \pm 2.07$ & $9.08 \pm 2.05^{\mathrm{ns}}$ & 71 \\
\hline $\operatorname{NAR}\left(\mathrm{mg} \mathrm{cm}^{-2}\right.$ day $\left.^{-1}\right)$ & $0.22 \pm 0.03$ & $0.15 \pm 0.03^{\mathrm{ns}}$ & 68 \\
\hline $\mathrm{LA}\left(\mathrm{cm}^{2}\right)$ & $455.4 \pm 40.9$ & $414.6 \pm 34.6^{\mathrm{ns}}$ & 91 \\
\hline $\operatorname{RMR}\left(\mathrm{g} \mathrm{g}^{-1}\right)$ & $0.25 \pm 0.01$ & $0.20 \pm 0.01^{\star *}$ & 80 \\
\hline $\operatorname{SMR}\left(\mathrm{g} \mathrm{g}^{-1}\right)$ & $0.33 \pm 0.01$ & $0.37 \pm 0.01^{\star}$ & 112 \\
\hline $\operatorname{LMR}\left(\mathrm{g} \mathrm{g}^{-1}\right)$ & $0.42 \pm 0.01$ & $0.44 \pm 0.01^{\mathrm{ns}}$ & 105 \\
\hline $\operatorname{LAR}\left(\mathrm{cm}^{2} \mathrm{~g}^{-1}\right)$ & $56.15 \pm 2.50$ & $59.99 \pm 2.73^{\text {ns }}$ & 107 \\
\hline SPADi & $46.0 \pm 1.17$ & $41.2 \pm 1.97^{\mathrm{ns}}$ & 90 \\
\hline
\end{tabular}

Statistical significance between non-flooded and flooded plants is given by the $\mathrm{t}-$ test $\left({ }^{\mathrm{ns}} \mathrm{p}>0.05 ;{ }^{*} \mathrm{p} \leq 0.05 ;{ }^{* *} \mathrm{p} \leq 0.01\right)$.

of deterioration. Root browning might be related to increased enzyme activity associated with anaerobic respiration, leading to excess ethanol production. According to a study by Lobo \& Joly (2000), when $\mathrm{O}_{2}$ supply is limited, an acceleration of glycolysis and anaerobic respiration leads to an excess of lactic acid production by the lactate dehydrogenase (LDH) enzyme to compensate the low energy production in mitochondrial respiration. However, as the cellular $\mathrm{pH}$ decreases, LDH decreases its activity and there is an increase in the activity of the alcohol dehydrogenase $(\mathrm{ADH})$ enzyme, which is responsible for the last stage of the alcoholic fermentation pathway (Xia \& Roberts, 1994). The acceleration of glycolysis is dependent on the supply of carbohydrates transported from the aerial part of the plant to the roots, or even from the stock of reserve starch in the root parenchyma and can contribute to the maintenance of the root metabolism when the supply of $\mathrm{O}_{2}$ is limited (Gravatt \& Kirby, 1998).

Because they are volatile, fermentation products (acetaldehyde and ethanol) can be eliminated by means of lenticels (Kozlowski, 2002) or stomata (Kreuzwieser et al., 2004). However, when production outstrips the ability of the plant to eliminate ethanol, it can reach toxic intracellular levels. In these cases, ethanol acts as an organic solvent and can promote the disruption of the plasma membrane by the solubilization of the lipid components, causing death and darkening of the roots. Thus, although young plants of $C$. lucens survived soil flooding for approximately one month, root browning indicates that ethanol production must have exceeded the elimination capacity, possibly causing the death of pre-existing roots and decreasing the growth of new roots.

The partial closure of stomata and decrease in the net photosynthetic rate have been verified in many tropical tree species under flooding conditions (Mielke \& Schaffer, 2010; Oliveira \& Joly, 2010; Gonçalves et al., 2013; Lira et al., 2013). The decrease in the mean values of gs in plants subjected to soil flooding may be related to the deterioration or decrease of root growth, thus reducing water absorption. Alternatively, the decrease in the mean values of A in plants subjected to soil flooding may be related to stomatal limitation caused by stomatal closure or to the non-stomatal limitation caused by a decrease in the activity of ribulose 1,5-bisphosphate carboxylase/oxygenase enzyme (Vu \& Yelenosky, 2006; Dalmolin et al., 2013) or by the photoinhibition of photosynthesis. In this case, the excess production of $\mathrm{NADPH}+\mathrm{H}+$ in the photochemistry is not used in the biochemistry of photosynthesis (Lavinsky et al., 2007) and the plant does not present efficient mechanisms for the elimination of energy excess (Mielke et al., 2003). The decreases observed in A and gs in the present study, and the fact that no significant difference between the mean values of the $\mathrm{A} / \mathrm{gs}$ ratio were found, are indicative that stomatal and non-stomatal limitations of photosynthesis might have occurred. In contrast, the high values of SPADi in both flooded and non-flooded plants indicate that the light collecting systems associated with the photochemical stage of photosynthesis were not compromised by soil flooding. 
The decrease in shoot growth (leaves and stems) may be due to the decrease in the net photosynthetic rate or to the decrease in leaf area due to leaf fall. In the present study, leaf fall was not observed; therefore, the decrease in shoot growth can be attributed to the decrease of A. Additionally, the mean values of LA, LMR, and LAR did not differ significantly between flooded and non-flooded plants. However, the increase in mean values of SMR, LMR, and LAR appear to have been due to the decrease of RGRr and, consequently, of the root biomass at the completion of the experiment. The mean values of RGRs and RGRl were practically unaffected by soil flooding. These results reinforce the above discussions, indicating that the decrease in growth observed in flooded plants was mainly caused by the decrease of the root biomass, which affects water transportation and nutrient assimilation, causing stomata closure and decreases in the net photosynthetic rate.

Tree species can be distinguished based on their patterns of response to soil flooding. Intolerant species usually present severe metabolic and physiological dysfunctions in the first few hours or days after flooding starts. An example of a species that is intolerant to soil flooding is the avocado (Persea americana) (Gil et al., 2009). Species that are tolerant to flooding, such as Taxodium distichum and Annona glabra (Allen et al., 1996) and Annona glabra (Mielke et al., 2005) present several anatomical, morphological, and physiological adaptations to maintain high growth rates even after long periods (months or years) of flood conditions. The third group is represented by partially tolerant species, which have characteristics that, even with the reduction of growth, can survive occasional periods of soil flooding. Examples of tree species partially tolerant to flooding are Prioria copaifera (Lopez \& Kursar, 1999), Genipa americana (Mielke et al., 2003), Calophyllum brasiliensis (Oliveira \& Joly, 2010), Genipa spruceana (Gonçalves et al., 2013), and Inga marginata (Bender et al., 2016). From the results obtained in the present study, it is possible that young plants of $C$. lucens fit into the third group, i.e., decreases in A and gs and in growth rates, mainly of roots, although the plants survived the soil flooding for approximately one month.

Copaifera plants are popularly known as copaibeiras or pau-dóleo, and generally have heights of 10 to $40 \mathrm{~m}$, and dense foliage composed of alternating composite pinnate leaves with leathery leaflets of 3 to $6 \mathrm{~cm}$ in length (Pio Corrêa, 1984). In the case of C. langsdorffii, the most well studied species in the genus, seed dispersal is carried out by birds (Motta \& Lombardi, 1990) or hydrocoral (Martins et al., 2008), indicating their potential use for restoration of degraded riparian forests. Oliveira (2012) verified that young plants of $C$. langsdorffii survived soil flooding for 30 days, without presenting chlorosis or foliar necrosis, despite the decrease in root growth, which was observed in the present study for $C$. lucens. In the present study, we demonstrated that young plants of C. lucens present a decrease in carbon fixation by photosynthesis, which is probably associated with a reduction in stomatal conductance caused by a diminution in root growth rate. Despite the decrease in growth, the plants did not show symptoms of severe stress caused by soil flooding, indicating that this species could be used for plantings enrichment in degraded riparian forests.

\section{CONCLUSION}

Based on these results and considering the conditions under which the study was carried out, we can conclude that young plants of C. lucens are able to tolerate soil flooding for a period of approximately one month, even though they showed significant decreases in root growth rate, stomatal conductance, and net photosynthetic rate. These results are indicative to the possibility of including C. lucens in the list of species indicated for the restoration of degraded riparian forests in regions where this species naturally occurs.

\section{ACKNOWLEGEMENTS}

Daniela B. Vidal was a Master's degree scholarship student at the Foundation for Research Support of the State of Bahia (FAPESB). The authors acknowledge the Terra Vista settlement and biologists Jose Lima da Paixão and Michaele Pessoa for providing the plant material used in this study. The authors also acknowledge the curator of the HUESC, Prof. Luiz Alberto Mattos Silva. Marcelo S. Mielke gratefully acknowledge CNPq (Brazilian National Council for Scientific and Technological Development) for the award of fellowship of scientific productivity (306531/2015-1). 


\section{SUBMISSION STATUS}

Received: 29 nov., 2016

Accepted: 24 jan., 2018

\section{CORRESPONDENCE TO}

\section{Marcelo Mielke}

Departamento de Ciências Biológicas, Universidade Estadual de Santa Cruz - UESC, Rodovia Jorge Amado, Km 16, CEP 45662-900, Ilheus, BA, Brasil

e-mail:msmielke@uesc.br

\section{REFERENCES}

Allen JA, Pezeshki SR, Chambers JL. Interaction of flooding and salinity stress on baldcypress (Taxodium distichum). Tree Physiology 1996; 16(1-2): 307-313. http:// dx.doi.org/10.1093/treephys/16.1-2.307. PMid:14871777.

Batista CUN, Medri ME, Bianchini E, Medri C, Pimenta JA. Tolerância à inundação de Cecropia pachystachya Trec. (Cecropiaceae): aspectos ecofisiológicos e morfoanatômicos. Acta Botanica Brasílica 2008; 22(1): 91-98. http://dx.doi. org/10.1590/S0102-33062008000100012.

Bender B, Capellesso ES, Lottici ME, Sentkovski J, Mielniczki-Pereira AA, Rosa LMG, Sausen TL. Growth responses and accumulation of soluble sugars in Inga marginata Wild. (Fabaceae) subjected to flooding under contrasting light conditions. Brazilian Journal of Biology 2016; ahead of print

Dalmolin AC, Dalmagro HJ, Lobo F, Antunes MZ, Ortíz CER, Vourlitis GL. Photosynthetic light and carbon dioxide response of the invasive tree, Vochysia divergens Pohl, to experimental flooding and shading. Photosynthetica 2013; 51(3): 379-386. http://dx.doi.org/10.1007/s11099013-0034-1.

Davanso VM, Souza LA, Medri ME, Pimenta JA, Bianchini E. Photosynthesis, growth and development of Tabebuia avellanedae Lor. Ex Griseb. (Bignoniaceae) in flooded soil. Brazilian Archives of Biology and Technology 2002; 45(3): 375-384. http://dx.doi.org/10.1590/S151689132002000300016 .

Ferreira DAC, Dias HCT. Situação atual da Mata Ciliar do Ribeirão São Bartolomeu em Viçosa, MG. Revista Árvore 2004; 28(4): 617-623. http://dx.doi.org/10.1590/ S0100-67622004000400016.

Gil PM, Gurovich L, Schaffer B, García N, Iturriaga R. Electrical signaling, stomatal conductance, ABA and Ethylene content in avocado trees in response to root hypoxia. Plant Signaling \& Behavior 2009.4: 100-108.
Gonçalves JFC, Melo EGF, Silva CEM, Ferreira MJ, Justino GC. Estratégias no uso da energia luminosa por plantas jovens de Genipa spruceana Steyerm submetidas ao alagamento. Acta Botanica Brasílica 2012; 26(2):391-398. http://dx.doi.org/10.1590/S0102-33062012000200014.

Gonçalves JFC, Melo EGF, Silva CEM, Ferreira MJ, Gomes IB. Crescimento, partição de biomassa e fotossíntese em plantas jovens de Genipa spruceana submetidas ao alagamento. Cerne 2013; 19(2): 193-200. http://dx.doi. org/10.1590/S0104-77602013000200003.

Gravatt DA, Kirby CJ. Patterns of photosynthesis and starch allocation in seedlings of four bottomland hardwood tree species subjected to flooding. Tree Physiology 1998; 18(6): 411-417. http://dx.doi.org/10.1093/treephys/18.6.411. PMid:12651366.

Herrera A. Responses to flooding of plant water relations and leaf gas exchange in tropical tolerant trees of a blackwater wetland. Frontiers in Plant Science 2013; 4: 106. http://dx.doi.org/10.3389/fpls.2013.00106. PMid:23641246.

Hunt R, Causton DR, Shipley B, Askew AP. A modern tool for classical plant growth analysis. Annals of Botany 2002; 90(4): 485-488. http://dx.doi.org/10.1093/aob/ mcf214. PMid:12324272.

Kozlowski TT. Physiological-ecological impacts of flooding on riparian forest ecosystems. Wetlands 2002; 22(3): 550-561. http://dx.doi.org/10.1672/0277-5212(2002)022[0550:PE IOFO]2.0.CO;2.

Kozlowski TT, Pallardy SG. Acclimation and adaptive responses of woody plants to environmental stresses. Botanical Review 2002; 68(2): 270-334. http://dx.doi. org/10.1663/0006-8101(2002)068[0270:AAAROW]2. $0 . \mathrm{CO} ; 2$.

Kreuzwieser J, Papadopoulou E, Rennenberg H. Interaction of flooding with carbon metabolism of forest trees. Plant Biology 2004; 6(3): 299-306. http://dx.doi. org/10.1055/s-2004-817882. PMid:15143438.

Lavinsky AO, Sant'Ana CS, Mielke MS, Almeida AAF, Gomes FP, França $S$ et al. Effects of light availability and soil flooding on growth and photosynthetic characteristics of Genipa americana L. seedlings. New Forests 2007; 34(1): 41-50. http://dx.doi.org/10.1007/s11056-006-9036-1.

Li M, López R, Venturas M, Pita P, Gordaliza GG, Gil L et al. Greater resistance to flooding of seedlings of Ulmus laevis than Ulmus minor is related to the maintenance of a more positive carbon balance. Trees 2015; 29(3): 835-848. http://dx.doi.org/10.1007/s00468-015-1163-x.

Lira JMS, Ferreira RA, Silva CD Jr, Santos EM No, Santana WS. Análise de crescimento e trocas gasosas de plantas de Lonchocarpus sericeus (Poir.) D.C. sob alagamento para uso na recuperação de matas de ciliares. Ciência Florestal 2013; 23(4): 655-665. http://dx.doi.org/10.5902/1980509812349.

Lobo PC, Joly CA. Aspectos ecofisiologicos da vegetação de mata ciliar do Sudeste do Brasil. In: Rodrigues RR, 
Filho FL. (eds.) Matas ciliares conservação e recuperação. São Paulo: Edusp; 2000.

Lopez OR, Kursar TA. Flood tolerance of four tropical tree species. Tree Physiology 1999; 19(14): 925-932. http:// dx.doi.org/10.1093/treephys/19.14.925. PMid:12651304.

Martins K, Santos JD, Gaiotto FA, Moreno MA, Kageyama PY. Estrutura genética populacional de Copaifera langsdorffii Desf. (Leguminosae - Caesalpinioideae) em fragmentos florestais no Pontal do Paranapanema, SP, Brasil. Revista Brasileira de Botanica. 2008; 31(1): 61-69. http://dx.doi. org/10.1590/S0100-84042008000100007.

Maxwell A, Capon SJ, James CS. Effects of flooding on seedling establishment in two Australian riparian trees with contrasting distributions: Acacia stenophylla A. Cunn ex Benth and Casuarina cunninghamiana Miq. Ecohydrology 2016; 9(6): 942-949. http://dx.doi.org/10.1002/eco.1691.

Medina CL, Sanches MC, Tucci MLS, Sousa CAF, Cuzzuol GRF, Joly CA. Erythrina speciosa (Leguminosae-Papilionoideae) under soil water saturation: morphophysiological and growth responses. Annals of Botany 2009; 104(4): 671-680. http://dx.doi.org/10.1093/aob/mcp159. PMid:19581282.

Medri ME, Ferreira AC, Kolb RM, Bianchini E, Pimenta JA, Davanso-Fabro VM et al. Alterações morfoanatômicas em plantas de Lithraea molleoides (Vell.) Engl. submetidas ao alagamento. Biological Sciences 2007; 29: 15-22.

Mielke MS, Almeida AAF, Gomes FP, Aguillar AG, Mangabeira PAO. Leaf gas exchange, chlorophyll fluorescence and growth responses of Genipa americana seedlings to soil flooding. Environmental and Experimental Botany 2003; 50(3): 221-231. http://dx.doi.org/10.1016/ S0098-8472(03)00036-4.

Mielke MS, Matos EM, Couto VB, Almeida AAF, Gomes FP, Mangabeira PAO. Some photosynthetic and growth responses of Annona glabra L. seedlings to soil flooding. Acta Botanica Brasílica 2005; 19(4): 907-913. http://dx.doi. org/10.1590/S0102-33062005000400025.

Mielke MS, Schaffer B. Photosynthetic and growth responses of Eugenia uniflora L. seedlings to soil flooding and light intensity. Environmental and Experimental Botany 2010; 68(2): 113-121. http://dx.doi.org/10.1016/j. envexpbot.2009.11.007.

Moraes MEB, Gomes RL, Thévenin JMR, Silva GS, Viana WCC. Análise da paisagem da Bacia Hidrográfica do Rio Almada (Ba) com base na fragmentação da vegetação. Caminhos de Geografia 2012; 13(41): 159-169.
Motta JC Jr, Lombardi JA. Aves como agentes dispersores de copaíba (Copaifera langsdorffii, (Caesalpiniaceae) em São Carlos, Estado de São Paulo. Ararajuba 1990; 1: 105-106.

Parolin P. Diversity and adaptations to flooding in trees of Amazonian floodplains. Pesquisas. Botânica 2012; 63: 7-28.

Oliveira AS. Tolerância ao encharcamento, alterações morfológicas e anatômicas em algumas espécies lenhosas tropicais [dissertação]. Brasília: Universidade de Brasília; 2012. $52 \mathrm{p}$.

Oliveira VC, Joly CA. Flooding tolerance of Calophyllum brasiliense Camb. (Clusiaceae): morphological, physiological and growth responses. Annals of Botany 2010; 24: 185-193.

Pio Corrêa M. 1984. Dicionário de plantas úteis do Brasil e das exóticas cultivadas. Vol. 2. Rio de Janeiro: Imprensa nacional. p. 370-375.

Rigamonte-Azevedo OC, Wadt PGS, Wadt LHO. Copaíba: ecologia e produção de óleo resina. Rio Branco: Embrapa Acre, 2004.

Sambuichi RHR. Lista de árvores nativas do sul da Bahia. In: Sambuichi RHR, Mielke MS, Pereira CE, editores. Nossas árvores: conservação, uso e manejo de árvores nativas do sul da Bahia. Ilheús: Editus; 2009.

Santos TA, Mielke MS, Pereira HAS, Gomes FP, Silva DCS. Trocas gasosas foliares e crescimento de plantas jovens de Protium heptaphyllum March (Burseraceae) submetidas ao alagamento do solo em dois ambientes de luz. Scientia Forestalis 2012; 40: 47-56.

Tundisi JG, Tundisi TM. Impactos potenciais das alterações do Código Florestal nos recursos hídricos. Biota Neotropica 2010; 10(4): 67-75. http://dx.doi.org/10.1590/S167606032010000400010 .

Vidal DB, Andrade IL, Andrade ELP, Mielke MS. Effects of submergence in water on seed germination and vigor of the Copaifera lucens (Fabaceae) seedlings. Journal of Forestry Research 2014; 25(4): 903-908. http://dx.doi. org/10.1007/s11676-014-0537-z.

$\mathrm{Vu}$ JCV, Yelenosky G. Photosynthetic responses of citrus trees to soil flooding. Physiologia Plantarum 2006; 81(1): 7-14. http://dx.doi.org/10.1111/j.1399-3054.1991.tb01705.x.

Xia JH, Roberts JKM. Improved cytoplasmic $\mathrm{pH}$ regulation, increased lactate efflux, and reduced cytoplasmic levels are biochemical traits expressed in root tips of whole maize seedlings acclimated to a low-oxygen environment. Plant Physiology 1994; 105(2): 651-657. http://dx.doi. org/10.1104/pp.105.2.651. PMid:12232232. 